\title{
Workers Protection with a Fixed-Term Employment Contract System based on the Employment Statutory Regulations
}

\author{
Muhammad Kamal
}

\author{
Faculty of Law, Universitas Muslim Indonesia, Indonesia \\ email correspondence: muhkamal.hidjaz@umi.ac.id
}

\begin{abstract}
This research aims to identify and understand the position of legal protection for workers with a system of fixed-term employment contracts in the aspects of work relations, protection, and wages based on Employment laws and regulations. This research uses an empirical normative research method which combines the normative legal approach with empirical research. The results of this study indicate that there are still many companies in Makassar City that do not implement statutory regulations, especially regarding workers 'rights, for example, workers' status based on fixed time or a Non-Specified term employment contract and wages that are not in accordance with the city's minimum standard. As for the conditions of the workers, based on the analysis result from the prescriptive aspect, there were 95 or $47.50 \%$ of 200 workers starting a cooperative relationship without making a written agreement. Furthermore, there are as many as 55 or $27.50 \%$ of 200 workers assess that in their work activities, they do not get rights, there are also as many as 110 or $55.00 \%$ of 200 workers do not know what the form of worker rights is. Furthermore, there were as many as 140 or $70.00 \%$ of the 200 workers who received compensation that did not match the minimum wage in 3 (three) companies in Makassar City. These problems can be resolved appropriately if Law no. 13 of 2003 is properly implemented by Labor Inspectors and Specialist Labor Inspectors as the person in charge based on Minister of Manpower Regulation (Permenaker) No. 33 of 2016.
\end{abstract}

Keywords: Legal Protection; Labor Inspector; Workers; Employment Relationship; Wages;

Date of Submission: August 31, 2020

Date of Publication: December 10, 2020

DOI: http://dx.doi.org/10.33096/substantivejustice.v3i2.89

\section{INTRODUCTION}

Legal protection for workers is a manifestation and effort to advance public welfare as stated in the preamble to the 1945 Constitution of the Republic of Indonesia. This is because workers have a very important and significant role in national economic activities, namely increasing productivity to encourage the development and economy of a country. As for the world of economy, the government must ensure the readiness of workers before carrying out work activities so that they become workers, both individually and in groups,

\section{(i) (2)}

This work is licensed under a Creative Commons Attribution 4.0 International License. 
in government and private agencies, and within the scope of production of goods and or services. Economic activity, especially the company as the employer, is closely related to the manpower, which in this case will become workers, where both parties establish a relationship through an employment contract. The contract will be considered correct if it refers to the statutory regulations. Furthermore, laws and regulations exist to provide legal protection for the contract makers so that a harmonious relationship is built between the two parties. The legal protection: ${ }^{1}$

"Protecting dignity, as well as recognition of human rights owned by legal

subjects based on legal provisions from arbitrariness or protecting one thing from other things."

With regard to employment, the above explanation provides meaning for the protection of rights, especially for workers. This emphasis is also based on the fact that every year, workers always commemorate the national labor day. In every oration, the orators demand their welfare as the core message. Such demands can not be separated from the implementation of the work system, in this case, the outsourcing system applied by the company to its workers. Outsourcing in Oxford Learner's Dictionaries is:2

"The process of arranging for somebody outside a company to do work"

The outsourcing according to Maurice F. Greaver is : ${ }^{3}$

"The act of transferring some of the company's activities and the right to take its satisfaction to another party (outside the provider), where this action is bound in a cooperation contract ."

On the other hand, legal protection for workers is regulated in the Law of the Republic of Indonesia Number 13 of 2003 concerning Employment (hereinafter referred to as Law No.13 of 2003). It is clear in the consideration of point $d$ in the preamble to Law no. 13 of 2003 stated that:

"Protection of workers is intended to guarantee basic rights of workers/labor and guarantee equal opportunity and treatment without discrimination on any basis to realize the welfare of workers/labor and their families while still paying attention to the progress of the business world."

The employment relationship between the company and employees is based on Article 56 of Law no. 13 of 2003 explicitly regulates that:

\footnotetext{
${ }^{1}$ Philipus M. Hadjon. (1987) Perlindungan Hukum Bagi Rakyat di Indonesia: Sebuah Studi tentang Prinsip-Prinsipnya, Penanganannya oleh Peradilan dalam Lingkungan Peradilan Umum dan Pembentukan Peradilan Administrasi Negara. Surabaya: PT. Bina IImu. p. 25.

${ }^{2}$ Hafid, M. I. (2020). Perlindungan Hukum Terhadap Pekerja Dalam Perjanjian Kerja Waktu Tertentu Berdasarkan Undang-Undang Nomor 13 Tahun 2003 Tentang Ketenagakerjaan (Studi Dinas Ketenagakerjaan Kota Makassar). Jurnal al-Hikmah, 21(2). https://doi.org/10.30737/transparansi.v2i2.449

${ }^{3}$ Jonaedi Efendi, Ismu Gunadi Widodo, \& Fifit Fitri Lutfianingsih. (2016) Kamus Istilah Hukum Populer. Jakarta: Kencana Prenada Media Group.
} 
(1) A employment contract is made for a specified or unspecified time.

(2) A employment contract for a specified period as referred to in paragraph (1) based on:

a. period of time; or

b. completion of a certain job.

Furthermore, Article 64 of Law no. 13 of 2003 stipulates that :

"The company may submit a portion of the implementation of the work to another company through a contract for chartering the work or the provision of worker/labor services made in writing."

From the provisions above, it can be understood that there is the same meaning between a Fixed-term Employment Contract ( $P K W T$ ) and outsourcing where the company submits the recruitment process to the status of the worker to another party/worker service provider so that the status of the worker is only a contract employee.

Based on data from the Central Statistics Agency (BPS) of the Republic of Indonesia, in February 2019 there were 136,183,032 workers, and 129,366,192 with a percentage of 95.99\% of the number of workers. ${ }^{4}$ Meanwhile, data from the Central Statistics Agency (BPS) of South Sulawesi Province, in February 2019 there were 4,159,838 workers, and $3,934,557$ with a percentage of $94.58 \%$ of the total number of workers. ${ }^{5}$

The data above can be used as a reference to assess that the number of workers in the labor force is very large. This data also shows that there are so many work relationships between companies and workers, especially in South Sulawesi. From this condition, Law no. 13 of 2003 regulates in detail the differences between the PKWT system and the nonspecified term employment contract (PKWT) system, so that not all workers build employment relationships with companies using the PKWT system.

Furthermore, CHAPTER X Law no. 13 of 2003 stipulates that:

1. Protection, consisting of Articles 67 - 87, among others:

a. Persons with Disabilities, Article 67;

b. Children, Articles 68 - 75;

c. Women, Article 76;

d. Working Hours, Articles 77 - 85;

e. Occupational Safety and Health, Articles 86 and 87.

2. Wages, consisting of Articles 88 - 98.

\footnotetext{
${ }^{4}$ Amalia, A., Ginting, B., Agusmidah, A., \& Yefrizawati, Y. (2017). Analisis Yuridis Perjanjian Kerja Waktu Tertentu Berdasarkan Undang-undang Ketenagakerjaan dan Hukum Perjanjian. USU Law Journal, 5 (1), 164960.

${ }^{5}$ Wildan, M. (2017). Perlindungan Hukum Tenaga Kerja Kontrak Dalam Perjanjian Kerja Waktu Tertentu Berdasarkan Undang-Undang No. 13 Tahun 2003 Tentang Ketenagakerjaan. Jurnal Hukum Khaira Ummah, 12(4), pp. 833-841.
} 
If a company uses the PKWT system for all its workers, it also ignores workers' rights, wages, and welfare, then the company is in violation of the law, and workers are obliged to get legal protection from the government.

Ironically, there are several findings where companies still ignore the provisions of Law no. 13 of 2003, among others, in the city of Semarang, there were cases of wage cuts by companies when female workers applied for menstrual leave, reduced number of days of leave and complicated procedures and conditions for applying for menstrual leave, pregnancy, childbirth, breastfeeding, and miscarriage. ${ }^{6}$ In Kediri City there are cases where companies do not make employment contracts when employing children, do not get parental permission, provide low wages, and long working hours. ${ }^{7}$ In Makassar City, there are two different cases which have been recorded as reports in the Industrial Relations Sector of the Makassar City Manpower Office with Number 560.568/1141/Disnaker-MKS /II/2019 regarding wages as a driver and Number 580.588/1171/Disnaker-MKS/IV/2019 regarding layoffs of workers at a hotel in Makassar.

As for responding to situations and conditions such as the above incident, in addition to the instruments of Law no. 13 of 2003 which has been described above, it is important to understand some implementing regulations so that protection of workers is not only limited to an echo of welfare for the community but also to be implemented in civic life. The regulations meant include: Presidential Regulation No. 21/2010 concerning Labor Inspection (hereinafter referred to as Perpres No. 21/2010), as an implementing regulation of Law No. 13 of 2003; as well as Regulation of the Minister of Manpower of the Republic of Indonesia Number 33 of 2016 concerning Labor Inspection Procedures (hereinafter referred to as Permenaker No. 33 of 2016), as an implementing regulation of Presidential Regulation No. 21 of 2010.

Based on the above background, the author formulates a question regarding the position of legal protection for workers with a system of fixed-term employment contract $(P K W T)$ in the aspects of work relations, protection, wages, and work welfare based on employment statutory regulations.

\section{METHOD}

This research uses the empirical normative research method which is a method that combines normative research methods with empirical study. The use of normative research methods because it uses primary legal materials, while the research method is empirical

\footnotetext{
${ }^{6}$ Ernita Manik. (2013). Implementasi Undang-Undang Nomor 13 Tahun 2003 tentang Ketenagakerjaan (Kasus Perlindungan Hak Pekerja/Buruh Perempuan pada Sektor Garmen di Kota Semarang). Journal of Politic and Government Studies, Universitas Diponegoro, 2(1). p. 28.

${ }^{7}$ Netty Endrawati. (2012). Perlindungan Hukum terhadap Pekerja Anak di Sektor Informal (Studi Kasus di Kota Kediri). Jurnal Dinamika Hukum, Universitas Jenderal Soedirman, 12(2). p. 282.
} 
study because there are materials obtained directly from respondents or informants who have been purposely determined. This research also uses secondary data where the data is research data obtained through intermediary media or indirectly in the form of books, records, existing evidence, or archives, both published and not generally published. The number of respondents was 200 workers with a fixed-term employment contract (PKWT) from 3 (three) companies in Makassar City. The three companies are engaged in the hotel sector, the animal feed industry, and the banking sector. The data analysis technique was carried out based on two aspects, among others:

1. Prescriptive, where the results of the study are described in the form of numbers and statistics based on obtaining data from the number of respondents. The statistical results are obtained from the frequency distribution formula: ${ }^{8}$

$$
\mathrm{P}=\frac{f}{\mathrm{n}} \times 100 \%
$$

2. 2. Descriptive, where the data will be presented in the form of a sentence.

\section{ANALYSIS AND DISCUSSION}

Law of the Republic of Indonesia Number 13 of 2003 concerning Employment is the foundation for the realization of a prosperous, just, and equitable society, both materially and spiritually. ${ }^{9}$ Because of the noble manifestation of Law no. 13 of 2003, the discussion on employment has never ended. The general course of employment/labor regulations can be seen from several legalizations, including:

1. The 1945 Constitution of the Republic of Indonesia;

2. Law of the Republic of Indonesia Number 12 of 1948 concerning Employment Act of 1948;

3. Law of the Republic of Indonesia Number 1 of 1951 concerning the Declaration of the Enactment of the Work Act of 1948 Number 12 of the Republic of Indonesia for All Indonesia;

4. Law of the Republic of Indonesia Number 21 of 1954 concerning Labor Agreements between Labor Unions and Employers;

5. Law of the Republic of Indonesia Number 14 of 1969 concerning Basic Provisions regarding Labor;

6. Law of the Republic of Indonesia Number 25 of 1997 concerning Employment;

8 Soerjono Soekanto, Hengkie Liklikuwata, \& Mulyana W. Kusumah. (1986). Kriminologi: Suatu Pengantar. Jakarta: Ghalia Indonesia. P. 268.

${ }^{9}$ General Section Explanations on Law No. 13 Tahun 2003. 
7. Law of the Republic of Indonesia Number 11 of 1998 concerning Amendments to the Enactment of Law Number 25 of 1997 concerning Employment;

8. Government Regulation in Lieu of Law of the Republic of Indonesia Number 3 of 2000 concerning Amendments to Law Number 11 of 1998 concerning Amendments to the Enactment of Law Number 25 of 1997 concerning Employment; and

9. Law of the Republic of Indonesia Number 28 of 2000 concerning Stipulation of Government Regulations in Lieu of Law Number 3 of 2000 concerning Amendments to Law Number 11 of 1998 concerning Amendments to the Enactment of Law Number 25 of 1997 concerning Employment into Laws.

Furthermore, Law no. 13 of 2003 has also gone through a series of material tests as a form of assurance of protection for laborers and workers. As for the Decision of the Constitutional Court of the Republic of Indonesia regarding the Review of Law Number 13 of 2003 concerning Manpower against the 1945 Constitution of the Republic of Indonesia, among others are based on the table below:

Table 1. The decision of the Constitutional Court regarding Case of Law No. 13 of 2003

\begin{tabular}{|c|c|c|c|}
\hline \multirow{2}{*}{ No. } & \multicolumn{2}{|c|}{ Case of Law No. 13 of 2003} & \multirow{2}{*}{$\begin{array}{c}\text { The decision of the Constitutional } \\
\text { Court }\end{array}$} \\
\hline & Number & Object & \\
\hline 1. & 012/PUU-I/2003 & $\begin{array}{l}\text { Article 158; Article } \\
\text { 159; Article } 160 \text { clause } \\
\text { (1); Article 170; Article } \\
\text { 171; Article } 186\end{array}$ & $\begin{array}{l}\text { partially granted the Petitioners' } \\
\text { petition. }\end{array}$ \\
\hline 2. & $\begin{array}{l}\text { 115/PUU- } \\
\text { VII/2009 }\end{array}$ & $\begin{array}{l}\text { Article } 120 \text { clause (1), } \\
\text { (2) dan (3) }\end{array}$ & $\begin{array}{l}\text { partially granted the Petitioner's } \\
\text { petition. }\end{array}$ \\
\hline 3. & 61/PUU-VIII/2010 & $\begin{array}{l}\text { Article } 1 \text { butir } 22 ; \\
\text { Article } 88 \text { clause (3) } \\
\text { huruf a; Article } 90 \\
\text { clause (2); Article } 160 \\
\text { clause (3) dan (6); } \\
\text { Article } 162 \text { clause (1); } \\
\text { Article } 171\end{array}$ & $\begin{array}{l}\text { reject the Petitioner's petition in its } \\
\text { entirety. }\end{array}$ \\
\hline 4. & 19/PUU-IX/2011 & Article 164 clause (3) & $\begin{array}{l}\text { partially granted the Petitioners' } \\
\text { petition. }\end{array}$ \\
\hline 5. & 27/PUU-IX/2011 & $\begin{array}{l}\text { Article 59; Article 64; } \\
\text { Article 65; Article } 66\end{array}$ & $\begin{array}{l}\text { partially granted the Petitioners' } \\
\text { petition. }\end{array}$ \\
\hline 6. & 37/PUU-IX/2011 & Article 155 clause (2) & granted the Petitioners' petition. \\
\hline 7. & 58/PUU-IX/2011 & $\begin{array}{l}\text { Article } 169 \text { clause (1) } \\
\text { letter c }\end{array}$ & $\begin{array}{l}\text { granted the Petitioner's petition in } \\
\text { its entirety. }\end{array}$ \\
\hline 8. & 61/PUU-X/2012 & Article 166 & $\begin{array}{l}\text { grant the withdrawal of the } \\
\text { Petitioner's petition. }\end{array}$ \\
\hline 9. & 100/PUU-X/2012 & Article 96 & $\begin{array}{l}\text { granted the Petitioner's petition in } \\
\text { its entirety. }\end{array}$ \\
\hline 10. & 117/PUU-X/2012 & Article 163 clause (1) & $\begin{array}{l}\text { reject the Petitioner's petition in its } \\
\text { entirety. }\end{array}$ \\
\hline
\end{tabular}




\begin{tabular}{|c|c|c|c|}
\hline \multirow{2}{*}{ No. } & \multicolumn{2}{|c|}{ Case of Law No. 13 of 2003} & \multirow{2}{*}{$\begin{array}{c}\text { The decision of the Constitutiona } \\
\text { Court }\end{array}$} \\
\hline & Number & Object & \\
\hline$\overline{c 11 .}$ & 67/PUU-XI/2013 & Article 95 clause (4) & $\begin{array}{l}\text { partially granted the Petitioners' } \\
\text { petition. }\end{array}$ \\
\hline 12. & 69/PUU-XI/2013 & $\begin{array}{l}\text { Article } 158 \text { clause (3) } \\
\text { dan (4); Article } 162 \\
\text { clause (1) dan (2) }\end{array}$ & $\begin{array}{l}\text { reject the Petitioner's petition in its } \\
\text { entirety. }\end{array}$ \\
\hline 13. & 96/PUU-XI/2013 & $\begin{array}{l}\text { Article } 59 \text { clause }(7) ; \\
\text { Article } 65 \text { clause (8); } \\
\text { Article } 66 \text { clause (4) }\end{array}$ & $\begin{array}{l}\text { reject the Petitioner's petition in its } \\
\text { entirety. }\end{array}$ \\
\hline 14. & 7/PUU-XII/2014 & $\begin{array}{l}\text { Article } 59 \text { clause (7); } \\
\text { Article } 65 \text { clause (8); } \\
\text { Article } 66 \text { clause (4) }\end{array}$ & $\begin{array}{l}\text { granted the Petitioner's petition in } \\
\text { its entirety. }\end{array}$ \\
\hline 15. & 11/PUU-XII/2014 & $\begin{array}{l}\text { Article } 88 \text { clause }(4) ; \\
\text { Article } 89 \text { clause }(3)\end{array}$ & $\begin{array}{l}\text { reject the Petitioner's petition in its } \\
\text { entirety. }\end{array}$ \\
\hline 16. & 72/PUU-XIII/2015 & Article 90 clause (2) & reject the Petitioner's petition. \\
\hline 17. & 1/PUU-XIV/2016 & Article 167 & $\begin{array}{l}\text { grant the withdrawal of the } \\
\text { Petitioner's petition. }\end{array}$ \\
\hline 18. & 8/PUU-XIV/2016 & Article 88 clause $(4)$ & $\begin{array}{l}\text { reject the Petitioner's petition in its } \\
\text { entirety. }\end{array}$ \\
\hline 19. & $\begin{array}{l}\text { 23/PUU- } \\
\text { XIV/2016 }\end{array}$ & Article 1 number 22 & $\begin{array}{l}\text { reject the Petitioner's petition in its } \\
\text { entirety. }\end{array}$ \\
\hline 20. & $\begin{array}{l}\text { 99/PUU- } \\
\text { XIV/2016 }\end{array}$ & $\begin{array}{l}\text { Article 6; Article } 57 \\
\text { clause (7); Article } 155 \\
\text { clause (2) }\end{array}$ & reject the Petitioner's petition. \\
\hline 21. & 13/PUU-XV/2017 & $\begin{array}{l}\text { Article } 153 \text { clause (1) } \\
\text { letter } \mathrm{f}\end{array}$ & $\begin{array}{l}\text { granted the Petitioner's petition in } \\
\text { its entirety. }\end{array}$ \\
\hline 22. & $\begin{array}{l}\text { 100/PUU- } \\
\text { XV/2017 }\end{array}$ & $\begin{array}{l}\text { Article 6; Article } 59 \\
\text { clause (7); Article } 86 \\
\text { clause (1) }\end{array}$ & $\begin{array}{l}\text { reject the Petitioner's petition in its } \\
\text { entirety. }\end{array}$ \\
\hline 23. & 6/PUU-XVI/2018 & Article 59 clause (1) & $\begin{array}{l}\text { reject the Petitioner's petition in its } \\
\text { entirety. }\end{array}$ \\
\hline 24. & $\begin{array}{l}\text { 42/PUU- } \\
\mathrm{XVI} / 2018\end{array}$ & Article 172 & reject the Petitioner's petition. \\
\hline 25. & $\begin{array}{l}\text { 46/PUU- } \\
\mathrm{XVI} / 2018\end{array}$ & Article 167 clause (3) & $\begin{array}{l}\text { reject the Petitioner's petition in its } \\
\text { entirety. }\end{array}$ \\
\hline 26. & $\begin{array}{l}\text { 68/PUU- } \\
\text { XVI/2018 }\end{array}$ & Article 167 clause (3) & reject the Petitioner's petition. \\
\hline 27. & $\begin{array}{l}\text { 72/PUU- } \\
\mathrm{XVI} / 2018 \\
\end{array}$ & Article 59 clause $(7)$ & reject the Petitioner's petition. \\
\hline 28. & $\begin{array}{l}\text { 75/PUU- } \\
\text { XVI/2018 }\end{array}$ & Article 167 clause (3) & reject the Petitioner's petition. \\
\hline 29. & $\begin{array}{l}\text { 77/PUU- } \\
\mathrm{XVI} / 2018\end{array}$ & Article 172 & $\begin{array}{l}\text { reject the Petitioner's petition in its } \\
\text { entirety. }\end{array}$ \\
\hline 30. & $\begin{array}{l}\text { 100/PUU- } \\
\text { XVI/2018 }\end{array}$ & Article 167 clause (3) & $\begin{array}{l}\text { reject the Petitioner's petition in its } \\
\text { entirety. }\end{array}$ \\
\hline 31. & $\begin{array}{l}\text { 101/PUU- } \\
\text { XVI/2018 }\end{array}$ & $\begin{array}{l}\text { Article } 156 \text { clause }(2) \\
\text { Article } 168 \text { clause (1) }\end{array}$ & reject the Petitioner's petition. \\
\hline
\end{tabular}

Source: Constitutional Court Website 2020

From table 1 above, it is important to be aware of the changes mentioned above because they will have an impact on legal protection for workers, especially with the PKWT system. 


\section{A. Legal Protection for PKWT Workers related to Employment Relations based on Law no. 13 of 2003}

The certainty of the status of the employment relationship in a company has a big effect on workers. This is because every human being needs clarity on the fulfillment of life, especially for his family. On the other hand, with the work relationship status, workers can plan a better life in the future. Therefore, based on Article 56 Law no. 13 of 2003 explicitly regulates that:

(1) An employment contract is made for a specified or unspecified time.

(2) An employment contract for a specified period as referred to in clause (1) based on:
a. period of time; or
b. completion of a certain job.

Furthermore, based on Article 57 Law no. 13 of 2003 stipulates that:

(1) An employment contract for a specified period of time is made in writing and must use Indonesian and Latin letters.

(2) An unwritten employment contract for a specified period of time is contradictory provided that the provisions referred to in clause (1) are stated as an employment contract for an unspecified period of time

(3) In the event that the employment contract is made in Indonesian and foreign languages, If there is a difference in interpretation between the two, then the employment contract made in Indonesian shall apply.

Furthermore, based on Article 59 clause (1) Law no. 13 of 2003 which regulates that an employment contract for a certain time can only be made for certain jobs which according to the type and nature or activity of the work will be completed within a certain time, namely:

a. once completed or temporary work;

b. work which is estimated to be completed in a time that is not too long and no longer than 3 (three) years;

c. work that is seasonal in nature; or

d. work related to new products, new activities, or additional products that are still in trial or investigation.

The provisions of the article above explain that apart from the type and nature or activities of the work that will be completed within a certain time, then the employment relationship between the company and the workers using the PKWT system is not justified. As based on Article 64 of Law no. 13 of 2003 stipulates that: 
"The company can submit part of the implementation of the work to other companies through a work contracting agreement or the provision of worker/labor services made in writing."

The provisions of the article above explain that companies that have sustainable activities, but build cooperative relationships with outsourcing companies or provide worker/labor services through contractual agreements based on a certain period of time so that workers only establish employment relationships with outsourcing companies and use the PKWT system. From this condition, workers have no relationship with the company where they are active. This is because workers build employment relationships with outsourcing companies so that the status of the employment relationship, protection, and worker wages is based on Article 65 of Law no. 13 of 2003.

As for knowing the implementation of the employment relationship of 200 workers with the PKWT system at 3 (three) companies in Makassar City, based on the results of the analysis from the prescriptive aspect, it can be seen in the table below.:

Table 2. The legitimacy of PKWT Workers related to Employment Relationships

\begin{tabular}{l|l|l}
\hline \hline Indicator & Frequency & Presentage \\
\hline \hline Written & 105 & $52,50 \%$ \\
\hline Unwritten & 95 & $47,50 \%$ \\
\hline \hline Total & 200 & $100,00 \%$ \\
\hline \hline
\end{tabular}

Source: respondent data after being processed on July 27, 2019

From table 2 above, there are as many as 95 or $47.50 \%$ of 200 workers with the PKWT system not in accordance with Article 57 clause (1) of Law no. 13 of 2003, so that when referring to Article 57 clause (1) Law no. 13 of 2003, the company is obliged to appoint these workers under the PKWT system based on Article 57 clause (2) Law no. 13 of 2003. However, the status of the 95 workers is still in a cooperative relationship with the PKWT system.

\section{B. Legal Protection for PKWT Workers related to Protection of Worker Rights based on Law no. 13 of 2003}

Based on Article 27 clause (2) of the 1945 Constitution of the Republic of Indonesia (hereinafter referred to as the $1945 \mathrm{NRI}$ Constitution) regulates that :

"Every citizen of the country has the right to work and a living that is decent for humanity."

Furthermore, based on Article 28D clause (1) of the 1945 NRI Constitution stipulates that:

(1) Everyone has the right to recognition, guarantee, protection, and Just legal certainty and equal treatment before the law. 
(2) Everyone has the right to work and to receive fair and proper compensation and treatment in an employment relationship.

As for the provisions of Part One CHAPTER X Law no. 13 of 2003 regulates the Protection of Worker Rights, among others:

1. People with disabilities;

2. Children;

3. Women;

4. Working Time;

5. Occupational Health and Safety.

From the above provisions, both the state and the company are obliged to provide work protection as the right of workers. As for knowing the implementation of the protection of the work rights of 200 workers with the PKWT system at 3 (three) companies in Makassar City, based on the results of the analysis from the prescriptive aspect, it can be seen in the table below:

Table 3. Understanding of PKWT Workers related to Work Protection

\begin{tabular}{l|c|c}
\hline Indicators & Frequency & Percentage \\
\hline \hline Providing Protection of Rights & 35 & $17,50 \%$ \\
\hline Does not provide protection for rights & 55 & $27,50 \%$ \\
\hline Do not know & 110 & $55,00 \%$ \\
\hline \hline Total & 200 & $100,00 \%$ \\
\hline \hline
\end{tabular}

Source: respondent data after being processed on July 27, 2019

Based on table 3 above, there are as many as 55 or $27.50 \%$ of 200 workers with the PKWT system assess that in their work activities, they do not get rights, there are also as many as 110 or $55.00 \%$ of 200 workers with the PKWT system assess that in their activities their work, they do not know what form of workers' rights as in the provisions of Part One CHAPTER X related to Protection of Law no. 13 of 2003. As for workers who feel they do not get rights while they are aware of this stipulation, it is because they are worried about their status as workers. This condition shows that the three companies have deviated from the provisions of Part One CHAPTER X regarding the Protection of Law no. 13 of 2003.

\section{Legal protection for PKWT workers related to wages based on Law no. 13 of 2003}

Based on Article 28D clause (2) of the 1945 NRI Constitution stipulates that:

"Everyone has the right to work and to receive fair and decent compensation and treatment in an employment relationship."

Furthermore, based on Article 88 Law no. 13 of 2003 stipulates that:

(1) Every worker/laborer has the right to earn adequate income a decent living for humanity. 
(2) In order to realize an income that fulfills a life worthy of humanity as referred to in clause (1), the government shall stipulate a wage policy that protects workers/laborers.

(3) The wage policy that protects workers/laborers as referred to in clause (2) covers:

a. minimum wage;

b. overtime pay;

c. wages for absence from work due to absence;

d. wages for absent from work because of other activities outside of work;

e. wages for exercising the right to take time off from work;

f. form and method of payment of wages;

g. fines and deductions from wages;

h. things that can be calculated with wages;

i. Wage structure and scale that is proportional;

j. wages for severance pay; and

k. wages for the calculation of income tax.

(4) The government sets the minimum wage as referred to in clause (3) letter a based on the need for a decent life and by taking into account productivity and economic growth.

Furthermore, based on Article 89 clause (1) Law no. 13 of 2003 stipulates that the minimum wage as referred to in Article 88 clause (3) letter a can consist of:

a. minimum wage based on Province or Regency / City area;

b. minimum wage by sector in the province or Regency / City.

Based on Article 90 clause (1) Law no. 13 of 2003 stipulates that :

"Entrepreneurs are prohibited from paying wages lower than the minimum wages as referred to in Article 89."

From the above provisions, the company is obliged to provide decent working wages for the workers. As for finding out the implementation of giving work wages of 200 workers with the PKWT system at 3 (three) companies in Makassar City, based on the results of the analysis from the prescriptive aspect, it can be seen in the table below:

Table 4. PKWT Employee Benefits related to Work Wages

\begin{tabular}{l|c|c}
\hline \hline Indicators & Frequency & Percentage \\
\hline \hline According to the Minimum Wage & 60 & $30,00 \%$ \\
\hline Not Matching the Minimum Wage & 140 & $70,00 \%$ \\
\hline \hline Total & 200 & $100,00 \%$ \\
\hline \hline
\end{tabular}

Source: respondent data after being processed on July 27, 2019

From table 4 above, there are as many as 140 or $70.00 \%$ of the 200 workers with the PKWT system who receive benefits that do not match the minimum wage. As the 
reason for workers who do not get their rights, this reason also applies to the conditions of workers who are not paid according to the minimum wage.

\section{Legal Protection for PKWT Workers based on Permenaker No. 33 of 2016}

It has been explained above that there are as many as 95 or $47.50 \%$ of 200 workers with the PKWT system starting a cooperative relationship without making a written agreement. Furthermore, as many as 55 or $27.50 \%$ of the 200 workers with the PKWT system considered that in their work activities, they did not get rights, there were also as many as 110 or $55.00 \%$ of the 200 workers with the PKWT system who did not know what the form of worker rights was. Furthermore, there are as many as 140 or $70.00 \%$ of the 200 workers with the PKWT system who get the compensation that does not match the minimum wage in 3 (three) companies in Makassar City.

From the data above, it has also been described based on Law no. 13 of 2003. As laws and regulations so that it can be implemented and the public can benefit from them, an implementing regulation is required which is ratified by both the President and his line ministries. As for addressing the three issues described above, it will be continued with the exposure of implementing regulations which are based on Article 3 Permenaker No. 33 of 2016 stipulates that:

(1) The purpose of the Labor Inspection is to ensure the implementation of employment Norms in Companies or Workplaces.

(2) The Labor Inspection functions :

a. guaranteeing employment law enforcement;

b. provide information and technical advice to Entrepreneurs and Workers / Laborers regarding things that can ensure effective implementation of employment statutory regulations; and

c. collect information about employment relations and conditions in the broadest sense as material for the preparation or improvement of labor laws and regulations.

Furthermore, based on Article 36 clause (2) letter a Permenaker No. 33 of 2016 stipulates that "testing of work norms" jo. Article 37 Permenaker No. 33 of 2016 stipulates that:

(1) Testing of work norms as referred to in Article 36 clause (2) letter a is carried out to ensure compliance with work norms requirements.

(2) The examination of work norms as referred to in clause (1) includes working time, rest time, wage system, work leave, female workers/laborers, child workers/laborers, job training, labor placement, social security for workers, welfare, morality, discrimination, work relations, freedom of association, opportunities to carry out worship according to their respective religions and beliefs. 
As for those who carry out work norms testing as referred to in the above provisions, based on Article 1 point 11 Permenaker No. 33 of 2016 means that:

"Specialized Labor Inspectors are Labor Inspectors who have special expertise appointed by the Minister to carry out Labor Norms testing in accordance with statutory regulations."

Furthermore, based on Article 38 clause (1), (2), and (3) Permenaker No. 33 of 2016 stipulates that:

(1) Testing of work norms as referred to in Article 37 clause (2), includes:

a. special testing; and

b. retest.

(2) The examination of work norms as referred to in clause (1) shall be carried out by the Labor Inspector who is a specialist of work norms and/or the Labor Inspector according to his / her position.

(3) The results of work norms testing as referred to in clause (1) are used as a reference in fulfilling Worker / Laborer's rights.

\section{CONCLUSION}

The results of this study indicate that there are still companies in Makassar City that do not carry out the statutory regulations, especially regarding workers' rights, for example, the status of workers based on a fixed-term employment contract or a non-fixed term contract and wages that are not in accordance with the city's minimum wage. The condition of the workers is based on the results of the analysis from the prescriptive aspect where there are as many as 95 or $47.50 \%$ of the 200 workers with the PKWT system start a cooperative relationship without making a written agreement. Furthermore, there are as many as 55 or $27.50 \%$ of 200 workers assess that in their work activities, they do not get rights, there are also as many as 110 or $55.00 \%$ of 200 workers do not know what the form of workers' rights is. Furthermore, there were as many as 140 or $70.00 \%$ of the 200 workers who received compensation that did not match the minimum wage in 3 (three) companies in Makassar City. These problems can be resolved appropriately if Law no. 13 of 2003 is properly implemented by Labor Inspectors and Specialist Labor Inspectors as the person in charge based on Minister of Manpower Regulation (Permenaker) No. 33 of 2016.

\section{REFERENCE}

Amalia, A., Ginting, B., Agusmidah, A., \& Yefrizawati, Y. (2017). Analisis Yuridis Perjanjian Kerja Waktu Tertentu Berdasarkan Undang-undang Ketenagakerjaan dan Hukum Perjanjian. USU Law Journal, 5 (1), 164960. 
Charda, S. (2015). Karakteristik Undang-Undang Ketenagakerjaan Dalam Perlindungan Hukum Terhadap Tenaga Kerja. Jurnal Wawasan Yuridika, 32(1), pp. 1-21. https://doi.org/10.25072/jwy.v32i1.86

Ernita Manik. (2013). Implementasi Undang-Undang Nomor 13 Tahun 2003 tentang Ketenagakerjaan (Kasus Perlindungan Hak Pekerja/Buruh Perempuan pada Sektor Garmen di Kota Semarang). Journal of Politic and Government Studies, Universitas Diponegoro, 2(1), pp. $21-31$.

Hafid, M. I. (2020). Perlindungan Hukum Terhadap Pekerja Dalam Perjanjian Kerja Waktu Tertentu Berdasarkan Undang-Undang Nomor 13 Tahun 2003 Tentang Ketenagakerjaan (Studi Dinas Ketenagakerjaan Kota Makassar). Jurnal al-Hikmah, 21(2). https://doi.org/10.30737/transparansi.v2i2.449

Jonaedi Efendi, Ismu Gunadi Widodo, \& Fifit Fitri Lutfianingsih. (2016). Kamus Istilah Hukum Populer. Jakarta: Kencana Prenada Media Group.

Law of the Republic of Indonesia Number 12 of 1948 concerning the Employment Act of 1948.

Law of the Republic of Indonesia Number 1 of 1951 concerning the Declaration of the Enactment of the Employment Act of 1948 Number 12 of the Republic of Indonesia for All Indonesia. State Gazette of the Republic of Indonesia Year 1951 Number 2.

Law of the Republic of Indonesia Number 21 of 1954 concerning Emplymen Contract between Labor Unions and Employers. State Gazette of the Republic of Indonesia Year 1954 Number 69. Supplement to State Gazette of the Republic of Indonesia Number 598.

Law of the Republic of Indonesia Number 14 of 1969 concerning Basic Provisions regarding Labor. State Gazette of the Republic of Indonesia of 1969 Number 55. Supplement to the State Gazette of the Republic of Indonesia Number 2912.

Law of the Republic of Indonesia Number 25 of 1997 concerning Employment. State Gazette of the Republic of Indonesia Year 1997 Number 73. Supplement to State Gazette of the Republic of Indonesia Number 3702.

Law of the Republic of Indonesia Number 11 of 1998 concerning Amendments to the Enactment of Law Number 25 of 1997 concerning Employment. State Gazette of the Republic of Indonesia Year 1998 Number 184. Supplement to the State Gazette of the Republic of Indonesia Number 3791. 
Law of the Republic of Indonesia Number 28 of 2000 concerning Stipulation of Executive Order in Lieu of Law Number 3 of 2000 concerning Amendments to Law Number 11 of 1998 concerning Amendments to the Enactment of Law Number 25 of 1997 concerning Employment Into Law. State Gazette of the Republic of Indonesia Year 2000 Number 240. Supplement to State Gazette of the Republic of Indonesia Number 4042.

Law of the Republic of Indonesia Number 13 of 2003 concerning Employment. State Gazette of the Republic of Indonesia Year 2003 Number 39. Supplement to State Gazette of the Republic of Indonesia Number 4279.

Law of the Republic of Indonesia Number 21 of 2003 concerning Ratification of the ILO Convention No. 81 concerning Labor Inspection in Industry and Commerce (ILO Convention No. 81 concerning Labor Inspection in Industry and Trade). State Gazette of the Republic of Indonesia of 2003 Number 91. Supplement to the State Gazette of the Republic of Indonesia Number 4309.

Muhammad Kamal. (2011). Prinsip-Prinsip Hukum Ekonomi Islam. Al-Fikr: Jurnal Pemikiran Islam, Universitas Islam Negeri Alauddin Makassar, 15(1), pp. 188 - 194.

Muin, F. (2015). Perlindungan Hukum Terhadap Tenaga Kerja Indonesia (Tinjauan Terhadap UU Nomor 39 Tahun 2004 Tentang Penempatan dan Perlindungan Tenaga Kerja Indonesia). Jurnal Cita Hukum, 3(1). https://doi.org/10.15408/jch.v2i1.1838

Netty Endrawati. (2012). Perlindungan Hukum terhadap Pekerja Anak di Sektor Informal (Studi Kasus di Kota Kediri). Jurnal Dinamika Hukum, Universitas Jenderal Soedirman, 12(2), pp. 270 - 283. doi: http://dx.doi.org/10.20884/1.jdh.2012.12.2.47

Nurul Qamar, et al. (2017). Metode Penelitian Hukum (Legal Research Methods). Makassar: CV. Social Politic Genius (SIGn).

Presidential Regulation of the Republic of Indonesia Number 21 of 2010 concerning Labor Inspection.

Philipus M. Hadjon. (1987). Perlindungan Hukum Bagi Rakyat di Indonesia: Sebuah Studi tentang Prinsip-Prinsipnya, Penanganannya oleh Peradilan dalam Lingkungan Peradilan Umum dan Pembentukan Peradilan Administrasi Negara. Surabaya: PT. Bina IImu. 
Volume 3, Issue 2, December 2020 : 180 - 195

Regulation of the Minister of Manpower of the Republic of Indonesia Number 33 of 2016 concerning Labor Inspection Procedures. State Gazette of the Republic of Indonesia of 2016 Number 1753.

Soerjono Soekanto, Hengkie Liklikuwata, \& Mulyana W. Kusumah. (1986). Kriminologi: Suatu Pengantar. Jakarta: Ghalia Indonesia.

The 1945 Constitution of the Republic of Indonesia.

Wildan, M. (2017). Perlindungan Hukum Tenaga Kerja Kontrak Dalam Perjanjian Kerja Waktu Tertentu Berdasarkan Undang-Undang No. 13 Tahun 2003 Tentang Ketenagakerjaan. Jurnal Hukum Khaira Ummah, 12(4), pp. 833-841. 